https://doi.org/10.18485/kud_kiaz.2019.ch25

Nigar Hagverdiyeva

Senior teacher

Azerbaijan University of Languages

\title{
AZERBAIJAN CULTURE IN TRADITIONAL AND MULTICULTURAL HARMONIES
}

\section{SUMMARY}

The article devoted to the actual question of cultural and multicultural harmonies that have great roles in the life of many different nations of today that is very global nowadays.

In this article is analyzed the main points of the ancient Azerbaijani traditions, its different aspects, especially the essential features of Azerbaijani language that underwent changes during the long period.

The main attention focused on the local and native art, cultural and traditional characters of Azerbaijani people and their language development during the past centuries.

Key words: multicultural, culture, intellectual development.

We live in contemporary society of a very multicultural world. Everything around us changes time by time, year by year and even day by day. So the society changes as a result, too. And it cannot be conceived without influence on language, literature and in one word, on culture in common. As an inhabitant of the land of Azerbaijan, the famous land of fire from birth, we live and feel these beautiful cultural features in our every day life. So every feature of this country's culture, as well as including the language and literary process is familiar to us in a clear manner. 
By saying culture very diverse fields of cultural realms appear in front of us. The great and very ancient culture of Azerbaijan reflected and imaged in our national songs, dances, poems, prose, verse, art and various paintings, drawings, carpets, silk cloth, films, celebrations, holidays, (one of the very outstanding marvellous holiday of nature Norouz) and some other areas, too.

For getting more clear depiction of the cultural elements of this nation it is important to know its local and national colour. All these features are reflected in the everyday and social life of people. The way of living, working and thinking is the main factor of cultural growth of nation. The contemporary life demands inreasing rapidly that points itself in intellectual development of nation, so the society. The society is the main reason and mentality that has the great impact to the increasing of language and literature. Its perfection is obviously seen from the art and literatute. For example, the language and literary works is the best mirror of the society it refers, or in other words, through the any literary works and their languages they present, we can get clear enough appearance, picturesque of society they created and reflected. When we read the works of great Azerbaijani thinkers Nizami Gendjevi, Mehemmed Fuzuli, Imadeddin Nesimi, Molla Penah Vagif, Huseyn Javid, Mirze Feteli Akhundov, Mirze Elekber Sabir, Semed Vurgun, Memmed Araz, Xelil Rza, Ramiz Rovshen and some others we can get enough imagination about the language difference and various literary environment, so the life conditions at that time they lived. All the literary works, literary trends appeared as a result of the same reason, the reason of life conditions and the changes in society and also in litrery environment.

Furthermore, the language in Nizami Gencevi's, Mehemmed Fuzuli's, Imadeddin Nesimi's period differs greatly from the language of other poets and writers mentioned above. So "Nesimi's writing style distinguishes widely with its very complicated and contrast forms" $\{1,256$.$\} We can$ compare the difference of some examples like Nesimi's these words in the following lines clearly: 
Adet budurur kim, dili dildâre vererler,

Dil getdi elimizden, dildâr bulunmaz.

Or

Mende sığar iki cahan, men bu cahâna sığmazam,

Gövher-i lâmekan menem, kövn ü mekâna sığmazam.

But in comparison of the language of XIV century poem, the wording of great poet Molla Penah Vagif from Shusha, in Karabagh sounds very different in later XVIII century.

Birzaman havada qanad saxlayın,

Sözüm vardır mənim sizə, durnalar!

Qatarlaşıb nə diyardan gəlirsiz?

Bir xəbər veriniz bizə, durnalar!

In this couplet of poem we see the very dissimilar language, in other words more contemporary one used in literary world in XVIII century in Azerbaijan.

But in the most contemporary literature of Azerbaijan we can see much clearer and more transparent, lucid and crystalline language, the language of Semed Vurgun, the other very outstanding poet of this land:

El bilir ki, sən mənimsən,

Yurdum, yuvam, məskənimsən,

Anam doğma vətənimsən!

Ayrılarmı könül candan?

Azərbaycan, Azərbaycan!

https://www.youtube.com/watch? $\mathrm{v}=5 \mathrm{sr} 7 \mathrm{sPr} 3 \mathrm{AKg}$

All these three poets of diverse styles lived and created various valuable works living in very different regions of Azerbaijan and the life conditions and wonderful nature of the places they lived influenced virtually on their creative activities.

Through the many centuries Azerbaijan culture passed the long way in flourishing. The people in early centuries were busy with different labour activities and handcrafts such as, cropping, farming, vine-growing, pottering, blacksmith, weaving, carpet-weaving, trading and some other doings. All these activities reflected themselves in the cultural life of 
Azerbaijan people. There are many national dances, folk art and songs, cave drawings and other national art forms that are composed and created with the influence of these activity fields.

But one of the first and very precious ancient cultural factor as a part of our tradition is our national song that is created by mothers- songs lullabies.

https:/www.youtube.com/watch?v=Pdd-ya3jXdY

Lullabies are improvised by our mothers and grannies for a long time and they are the mothers and also grandmothers' beautiful desires for their children's future destiny and all of them are composed on national and ancient poem genre bayati, a kind of Azerbaijani poem created by common people. Old people in early years used to say and liked to tell bayaties. So the bayati is one of the ancient and national kinds of poem.

Ozizim kətan yaxş1,

Keyməyə kətan yaxş1,

Qürbət yer cənnət olsa,

Yenə də vətən yaxş1.

$* * *$

Burda yolum oldu tən,

Varmı bu yoldan ötən,

Bu dünyaya şirin şey,

Bir anadır, bir Vətən.

$* * *$

Әzizim qərib ölkə

Gəzməyə qərib ölkə

Ölməyə vətən yaxş1.

https://www.youtube.com/watch?v=fSuRaYaaUR8

Here it must be emphasized that bayaties are very popular not only in Azerbaijan, but it is also very videly used by other turkish language peoples, like ozbekh, gazakh, qirghiz, turkmen, turks, bashqird and it is much famous among all other turkish peoples.

Furthermore, it must be depicted one more very important detail that all of the counted cultural works follow the great Turkish literary monumental epos of Dede Qorgud 
or Dede Korkut. The first manuscript of "The Book of Dede Gorgud", dated to the 16th century and consisting of 1 preface and 12 stories (songs). According to scholars this epos concerns the events occuring in Azerbaijan particularly in the X or XI centries. :At the same time this epos is called like "Oguzname" which means the narration about one of the longstanding Turkish nation. The manuscript of "The Book of Dede Gorgud" is now kept at the library of Dresden”.1,20\}

Azerbaijan is also known with its very ancient, antique, longstanding simbol of culture Gobustan Rock Art in Gobustan Preserve.

Old City or Inner City (İçəri Şəhər) is the historical core of Baku, the capital of Azerbaijan. The other historical edifice is Maiden Tower is also very popular.

When speaking about our culture we can not forget about one of the antique culture of Azerbaijan land Karabagh traditions. Karabagh is great and national part of Azerbaijan. Karabakh is a geographic region in southwestern Azerbaijan, extending from the highlands of the Lesser Caucasus down to the lowlands between the rivers Kura and Aras.

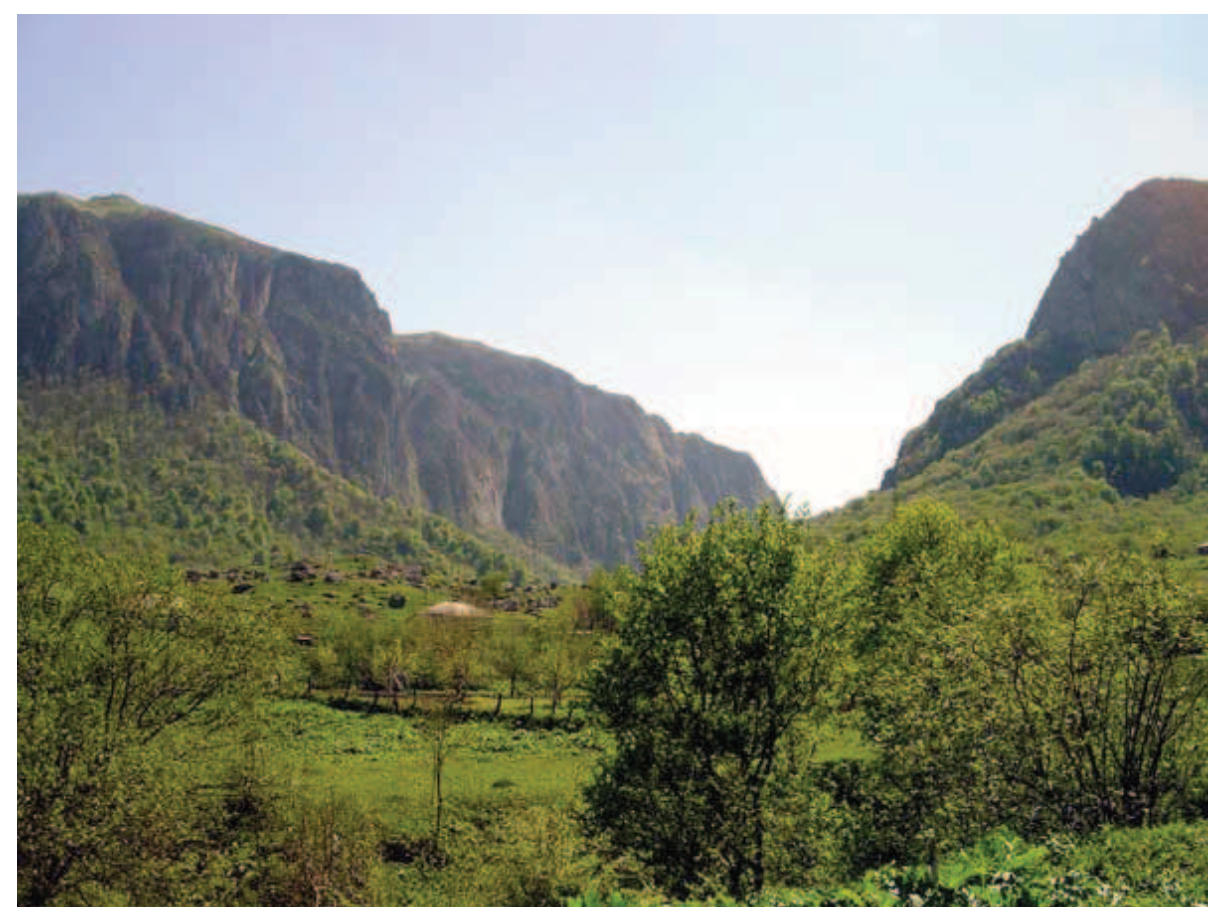




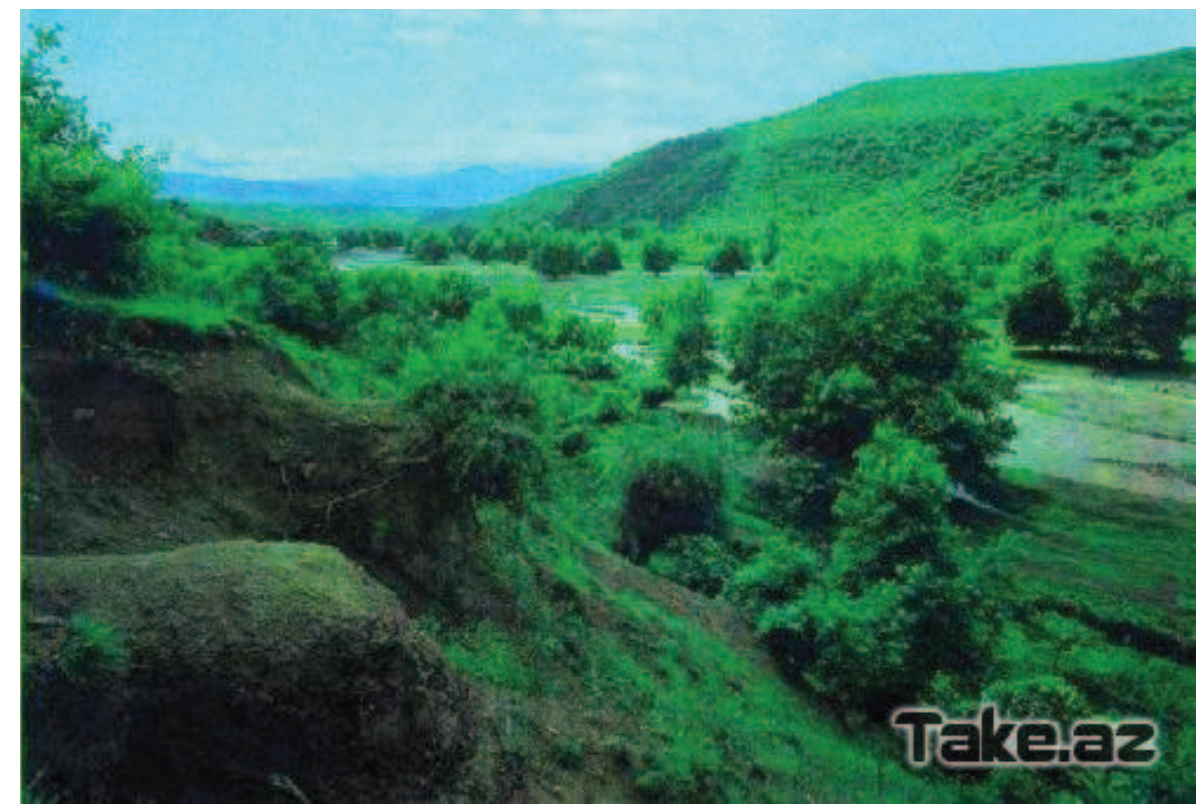

The old music of mugam performance began in this land and in the center of Karabagh Shusha. Great mugam singers like Cabbar Qaryaghdioglu, Seyyid Shushunski, Khan Shushinski and some others were very popular not only in Karabagh, but also in Azerbaijan, too. Karabagh culture is very popular with its famous carpets, rugs, horses, historical places and buildings and cuisines, too. Here is interesting to depict that the very rare flower in the world by name Khari bulbul ("Xarı bülbül" in Azerbaijani) grow only in Karabagh and it is the symbol of lovely Karabagh land.
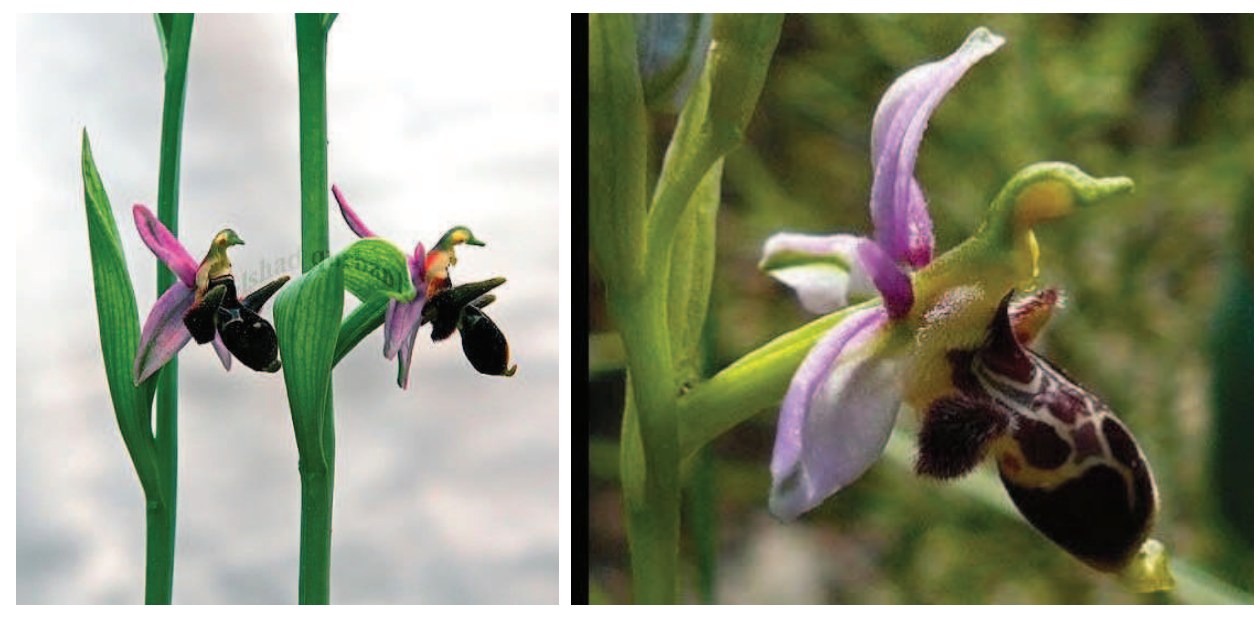
The first eastern opera music was composed by Uzeir Hajibeyov who grew up in Karabagh and lived in his young years here.

Besides all the arguments and details mentioned above it is also very actual matter to emphasize the multicultural life harmonies going on nowadays in our country, so that there are also great many national minorities, some ethnic groups living together with our nation in peace conditions in this land. The Azerbaijan government founded all the constant, essential and needful life conditions for these people's welfare, too. The different minor nations such as, jews, talishes, kurds, tats, avars, sakhurs, lazgies, rutulls, molokans, ingiloys, gipsies, assirialies, udies, germans, russions and some others with their ethnic flavour keep their customs and still continue their activities in different fields at the present time. The national attitudes, relations and living terms among the ethnic groups last from past in harmony, in unit family, and mutual understanding and respecful conditions and these ties still live and continue even nowadays. All these minor nations have their own diverse cultual rituals, religious, national traditions that still endure till present days. One can see great and tough harmonies among the traditons of Azerbaijan people with the traditions of the minor ethnic groups living in Azerbaijan.

Even there are already some cultural commonalities and links between Azerbaijan people and the people of these ethnic groups, such as, wedding, celebrations, cuisine, music, dances, songs, visit, family customs and some others.

The relationship between Azerbaijan and other nations increase day by day and Azerbaijan is traditionally always very tolerant accepting other nations in its country.

Anyone can get very broad information about our wonderful country from the magazine "Visions of Azerbaijan", too. In this magazine various articles are published about every field of native Azerbaijan and its magnificent culture. 


\section{Literature:}

Hemid Arasli. Azerbaijan literature:History and problems. Baki.1998.p.732

M.Jelal, F.Huseynov. Azerbaijani literature. Baki. 1982. p.428

M.Jelal, P.Khalilov. Bases of literary studies. Baki. 1972. p.280

Fuzuli. Selected Volumes. Baki. 1992. p.384

Mehemmed Fuzuli. Baki, 1986. p.482

Karabakgnameler,Baki.1989. p.192.

Visions of Azerbaijan. 2009. Volume 4.1

http://anl.az/el/emb/inesimi.pdf

http://sonuncuesr.com/hurufi-teriqeti-imadeddin-nesimiyaradiciligi/

https://www.youtube.com/watch?v=7xmLwXE_VUc

https://www.youtube.com/watch?v=UBDkJoPsEQM

https://www.youtube.com/results?search_query=azerbaijan+cultu re + and + traditions $+\& s p=m A E B$

\section{PЕЗЮМЕ}

Статья посвящена актуальному вопросу культурных и мультикультурных гармоний, которые играют огромную роль в жизни многих разных наций современности, которая сегодня носит очень глобальный характер.

В данной статье анализируются основные моменты древних азербайджанских традиций, их различные аспекты, особенно существенные особенности азербайджанского языка, которые претерпели изменения в течение длительного периода.

Основное внимание было уделено местному и родному искусству, культурным и традиционным персонажам азербайджанского народа и их языковому развитию в течение последних веков.

Ключевые слова: мультикультуральный, культура, интеллектуальное развитие. 